\title{
Evaluation of Index of Cardiac Electrophysiological Balance in Type 1 Diabetes Mellitus
}

\author{
Tip 1 Diabetes Mellitusta Kardiyak Elektrofizyolojik Denge İndeksinin \\ Değerlendirilmesi
}

\author{
Çağrı ZORLU ${ }^{1} \mathbb{D}$, Sefa Erdi ÖMÜR ${ }^{1}(\mathbb{D}$ \\ ${ }^{1}$ Tokat State Hospital Cardiology Clinic, Tokat/TURKEY
}

\begin{abstract}
Background: Type 1 diabetes mellitus (T1DM) has been suggested to carry the risk of developing cardiac arrhythmias. The risk of cardiovascular events and sudden death is higher in patients with T1DM. The index of cardiac electrophysiological balance (iCEB), which shows the balance between ventricular depolarization and repolarization, is a new electrocardiographic (ECG) parameter when compared to other ECG parameters. iCEB provides more information on ventricular arrhythmogenesis than the other traditional ECG parameters such as QT and corrected QT (QTc) intervals. The aim of this study is to evaluate the relationship between T1DM and iCEB.

Materials and Methods: This study was conducted retrospectively. The patient group consisted of 50 patients ( $58 \%$ male, mean age $32.9 \pm 8.7$ years) diagnosed with T1DM, while the control group consisted of 50 healthy individuals ( $58 \%$ male, mean age $33.9 \pm 6.8$ years). The clinical, demographic and ECG records of the patients were obtained from our hospital's medical documentation system. iCEB and corrected iCEB (iCEBC) values of all participants were calculated by dividing the relevant QT and QTc intervals by the QRS duration. Results: Mean PR, QRS, and QT intervals were similar between groups, while mean heart rate and QTc interval were found to be higher in the T1DM group than in healthy subjects [( $83.1 \pm 9.8 \mathrm{vs} 78.9 \pm 13.3 \mathrm{bpm}$, respectively, $p=0.019)$ and $(425 \pm 20.4$ vs $397.6 \pm 10.6 \mathrm{~ms}$, respectively, $p<0.001)$ ]. The iCEBc of the patient group with T1DM was higher than the control group ( $5.1 \pm 0.5$ vs $4.7 \pm 0.4 \mathrm{~ms}, p<0.001$, respectively). However, there was no significant difference in $\mathrm{C} C \mathrm{~B}$ between the patient and control groups $(4.3 \pm 0.4$ and $4.3 \pm$ $0.4 \mathrm{~ms}$, respectively, $\mathrm{p}=0.402$ ).

Conclusions: In our study, iCEBc was found to be significantly increased in T1DM patients compared to healthy subjects. Consequently; it is important to evaluate the risk of ventricular arrhythmia with iCEBc in T1DM patients.
\end{abstract}

Key Words: Electrocardiography, Index of cardiac electrophysiological balance, Type 1 diabetes mellitus, Ventricular arrhythmia

Öz.

Amaç: Tip 1 diabetes mellitus' un (T1DM) kardiyak aritmi geliştirme riski taşıdığı öne sürülmüștür. T1DM'li hastalarda kardiyovasküler olay ve ani ölüm riski daha yüksektir. Ventriküler depolarizasyon ve repolarizasyon arasındaki dengeyi gösteren kardiyak elektrofizyolojik denge indeksi (iCEB), diğer EKG parametreleri ile karşılaştıııldı̆ıında yeni bir elektrokardiyografik (EKG) parametredir. iCEB, QT ve düzeltilmiş QT (QTC) aralıkları gibi diğer geleneksel EKG parametrelerine göre ventriküler aritmogenez hakkında daha fazla bilgi sağlar. Bu çalışmanın amacı, T1DM ve iCEB arasındaki ilişkiyi değerlendirmektir.

Materyal ve Metod: Bu retrospektif çalışma, T1DM tanısı almış toplam 50 hasta ile (\% 58 erkek, ortalama yaş $32.9 \pm 8.7$ yıl) kontrol gurubunu oluşturmak üzere 50 sağlıklı denekten (\% 58 erkek, ortalama yaş $33.9 \pm$ 6.8 yıl) oluşmaktadır. Katılımcıların demografik, klinik ve EKG özellikleri hastanemizin tıbbi tıbbi dökümentasyon sisteminden elde edildi. iCEB ve düzeltilmiş iCEB (iCEBc) değerleri, ilgili QT ve QTc aralıklarının QRS süresine bölünmesiyle hesaplandı.

Bulgular: Ortalama PR, QRS ve QT aralıkları gruplar arasında benzer iken, ortalama kalp hızı ve QTc intervali T1DM grubunda sağ|ıkı bireylere göre daha yüksekti [(sırasıyla $83.1 \pm 9.8^{\prime}$ e karşı $78.9 \pm 13.3$ atım/dakika, $p=0.019)$ ve $\left(425 \pm 20.4^{\prime}\right.$ e karşı $\left.\left.397.6 \pm 10.6 \mathrm{~ms}, \mathrm{p}<0.001\right)\right]$. T1DM grubu kontrollere göre daha yüksek iCEBc' ye sahipti (sırasıyla $5.13 \pm 0.5$ 'e karşı $4.71 \pm 0.4 \mathrm{~ms}, p<0.001$ ). Bununla birlikte, gruplar arasında iCEB açısından anlamlı bir saptanmadı (sırasıyla $4.38 \pm 0.45$ ve $4.33 \pm 0.41 \mathrm{~ms}, p=0,402$ ).

Sonuç: Çalışmamızda iCEBc' nin, T1DM hastalarında sağlıklı kişilere kıyasla önemli ölçüde artmış olduğu bulundu. Bu nedenle; T1DM hastalarında ventriküler aritmi riskinin iCEBc ile değerlendirilmesi önem taşımaktadır.

Anahtar kelimeler: Elektrokardiyografi, Kardiyak elektrofizyolojik denge indeksi, Tip 1 diyabetes mellitus, Ventriküler aritmi

\section{Corresponding Author / Sorumlu Yazar}

\author{
Dr. Çağrı ZORLU \\ Tokat State Hospital \\ Cardiology Clinic, \\ Tokat/TURKEY
}

E-mail: zorlufb@hotmail.com

Received / Geliş tarihi: 30.04.2021

Accepted / Kabul tarihi: 21.10.2021

DOI: 10.35440/hutfd.930461 


\section{Introduction}

Diabetes mellitus (DM) is a serious health problem and is also associated with cardiovascular diseases. Diabetes mellitus is one of the risk factors of diseases such as coronary artery disease, cerebrovascular disease, hypertension, heart valve disease, peripheral artery disease, retinopathy and atrial fibrillation, while long-term exposure further increases this risk. On the other hand, it is also associated with increased mortality independently of these conditions (1). In an article examining young people with type $1 \mathrm{DM}$ (T1DM), they have a six-fold increased risk for QT/QTc prolongation and should be followed regularly for cardiac autonomic dysfunction (2). In this study, T1DM patients had a significantly longer QT/QTc than controls, but the significance disappeared after adjusting for confounding factors. More specific parameters of QT/QTc were investigated in later studies. In later studies, parameters which give information about the susceptibility to arrhythmia were revealed by measurements made on electrocardiography such as increased PR interval, T peak to T end interval (Tp-Te), dispersion of QT interval, and dispersion of $P$ wave (3-5). However, the cardiac electrophysiological balance index (ICEB), calculated from the surface ECG of the patients - is an indicator of the balance between cardiac depolarization and repolarization (6) - although it may be an indicator of ventricular arrhythmia, it has not been studied as much as other parameters (7).

The aim of this study is to evaluate the relationship between T1DM and iCEB.

\section{Materials and Methods Study populations}

Our study population consisted of healthy-looking individuals older than 18 years and diagnosed with T1DM, who visited our institution's cardiology outpatient clinic between July 2018 and May 2020. The number of T1DM patients was 50 and the number of healthy volunteers was 50 . The exclusion criteria were: electrolyte imbalances (e.g. hyperkalemia, hypopotassemia, etc.), systemic diseases (e.g. glycogen storage diseases, systemic lupus erythematosus, amyloidosis, lipid storage diseases, lysosomal storage diseases, etc.) and subjects who were using any drug other than oral or intravenous insulin (e.g. beta-blockers, antiplatelet, calcium channel blockers, angiotensin receptor blockers, angiotensin receptor - neprilysin inhibitor, angiotensin-converting enzyme blockers, antidepressant drugs), pregnancy, open thoracic surgery, history of moderate to severe heart valve disease, heart failure, pulmonary hypertension, acute kidney failure, coronary artery disease, retinopathy, cerebrovascular and peripheral vascular disease, malignancy and getting dialysis. The control group of the study was selected from healthy subjects who applied to the outpatient clinic anddid not have DM. Transthoracic echocardiography was performed in all patients included in the study. The patient and control groups were evaluated through medical history, echocardiography, physical examination, ECG, and laboratory data. Approval was obtained from the ethics committee of the Tokat Gaziosmanpasa University -date: 19.08.2020, number: 20-KAEK-123- where our institution was conducted.

\section{Laboratory and Demographic Data}

Biochemical parameters were automatically evaluated with the aid of the Beckman Coulter LH-750 Hematology Analyzer (Beckman Coulter, Inc, Fullerton, California). Blood samples of the patients were taken after 15 minutes of rest and the patients were asked not to smoke. The lipid panel of the patients [total cholesterol, low-density lipoprotein cholesterol (LDL), triglyceride and high-density lipoprotein cholesterol $(\mathrm{HDL})]$, were evaluated by standard methods. For the diagnosis of hypercholesterolemia, the patients were expected to have a total cholesterol value above $200 \mathrm{mg} / \mathrm{dL}$ or an LDL value above $130 \mathrm{mg} / \mathrm{dL}$ and had previously received treatment or diagnosis for hypercholesterolemia. The American Diabetes Association criteria were used for the diagnosis of T1DM; and patients who were previously diagnosed by a specialist in endocrinology were included in the study (8). For the diagnosis of hypertension, repeated systolic/diastolic blood pressure measurements were made and patients whose measurements were above $140 / 90 \mathrm{mmHg}$ were considered hypertensive. Patients who had been smoking for the last six months were evaluated as smokers. Body mass index can be calculated by dividing body mass in kilograms by the square of body length in meters.

\section{Echocardiographic evaluations}

Echocardiographic evaluations of the patient and the control groups were performed with the Vivid S5 echocardiography device (General Electric, Milwaukee, WI, USA) in the echocardiography unit of our center on all participants in the left decubitus position using a $2.5-3.5 \mathrm{MHz}$ transducer. All echocardiographic evaluations were performed separately by two cardiologists. Left ventricular ejection fractions (LVEF) of all participants were performed according to the American Echocardiography Association and the European Society of Cardiovascular Imaging criteria using the modified Simpson's method (9).

\section{Electrocardiographic assessment}

The 12-lead ECG (Cardiofax V; Nihon Kohden Corp., Tokyo, Japan; $10 \mathrm{~mm} / \mathrm{mV}$ and $25 \mathrm{~mm} / \mathrm{s}$ ) was taken while all participants were at rest in the supine position. Electrocardiograms obtained from all participants were sent to a computer via a scanner and analyzed and evaluated with $\times 400 \%$ using the Adobe Photoshop CS2 program (Adobe Systems Inc., San Jose, California, USA). ECG evaluations of all groups were performed separately by two cardiologists. Tp-e and QT intervals were measured and calculated by means of ECGs in the patient and control groups. The interval from the peak of the $T$ wave to the end of the $T$ wave was defined to 
as the Tpe interval and QT interval was measured from the onset of the QRS complex to the end of the T-wave (10). The measurements of QT and R-R intervals in all participants were made from the precordial leads V2 and V5. The value taken as the QT interval was defined as the time interval between the onset of the QRS wave and the point where the T wave turns to the isoelectric line on the ECG.

$R-R$ interval was evaluated on the ECG from the precordial leads and measured as the average of three consecutive beat complexes. The Bazett formula was used to calculate the QTc interval and the heart rate (11). Patients with $U$ waves in the ECG were not included in the study. The interval at the end of the electrocardiographic T-wave peak corresponding to the transmural dispersion of the repolarization was measured as Tp-e.

Index of cardiac electrophysiological balance was defined and measured as the ratio of QT to QRS (QT/QRS); while the corrected index of cardiac electrophysiological balance (iCEBc) was defined and measured as the ratio of QTc to QRS (QTC/QRS).

\section{Statistics}

Statistical analysis of the study was performed using SPSS 18.0 (SPSS Inc., Chicago Illinois, USA). Categorical variables were expressed as number and percentage ( $\mathrm{n} \%)$, while continuous variables were expressed as mean \pm standard deviation (mean $\pm \mathrm{SD}$ ) or median, interquartile range (median, IQR) according to the distribution of the data. In our study, the Kolmogorov-Smirnov test was used to evaluate the distribution of continuous variables. Normally distributed data were analyzed with the Student's t-test while non-normally distributed data were analyzed with the Mann-Whitney U test. Categorical variables were analyzed using the Fisher's exact or chi-square tests. Values with a $p$-value of $<0.05$ were considered statistically significant.

\section{Results}

Our study consists of 50 patients with T1DM and a control group of 50 participitans. The mean patient age was $33 \pm 7$ years, and 29 (58\%) of the patients were men. Fifty patients (50\%) had the T1DM pattern and were classified in the T1DM group. The remaining 50 (50\%) participants who had not to T1DM were classified in a control group. There was no statistically significant difference based on the baseline characteristics of the groups. The characteristics of the participants included in the study are shown in table 1.

There were no statistically significant differences in the median PR, mean QRS, and mean QT intervals in the ECG of the participants, and these parameters seemed to be within normal limits between the groups. On the other hand, the groups are compared; the mean heart rate and QTc interval in the T1DM group were found to be greater than in the healthy subjects $[(83.1 \pm 9.8$ vs $78.9 \pm 13.3 \mathrm{bpm}, \mathrm{p}=0.019)$ and $(425 \pm 20.4$ vs $397.6 \pm 10.6 \mathrm{~ms}, \mathrm{p}<0.001)$ ]; the mean R$R$ interval in the T1DM group was shorter than in the healthy group (729.5 \pm 61.5 vs $769 \pm 108 \mathrm{~ms}, \mathrm{p}=0.036)$. In addition, the groups were compared; we found that the mean Tp-Te time in the T1DM group was statistically significantly prolonged compared to the healthy group (79.1 \pm 6.4 vs $73.2 \pm$ $5.3 \mathrm{~ms}$, respectively, $\mathrm{p}=0.029)$. All these ECG data findings are given in table 2 .

Table 1. Baseline characteristics of the study groups

\begin{tabular}{|c|c|c|c|}
\hline & $\begin{array}{l}\text { T1DM group } \\
\quad(n=50)\end{array}$ & $\begin{array}{l}\text { Control group } \\
(n=50)\end{array}$ & $P$ value \\
\hline Age, years & $32.9 \pm 8.7$ & $33.9 \pm 6.8$ & 0.986 \\
\hline Male, n (\%) & $29(58)$ & $29(58)$ & 1.000 \\
\hline $\mathrm{BMI}, \mathrm{kg} / \mathrm{m} 2$ & $24.3 \pm 4.8$ & $24.2 \pm 4.9$ & 0.984 \\
\hline Smoking, n (\%) & $8(16)$ & $9(18)$ & 0.684 \\
\hline Glukoz, mg/dL & $152.8 \pm 40.2$ & $96 \pm 11$ & $<0.001$ \\
\hline $\mathrm{HbA} 1 \mathrm{c}, \%$ & $8.2 \pm 1.1$ & $5.3 \pm 1$ & $<0.001$ \\
\hline Creatinine, $\mathrm{mg} / \mathrm{dL}$ & $0.7 \pm 0.2$ & $0.8 \pm 0.2$ & 0.546 \\
\hline $\begin{array}{l}\text { Systolic Blood Pressure, } \\
\mathrm{mmHg}\end{array}$ & $125.5 \pm 7.8$ & $122.1 \pm 7.6$ & 0.058 \\
\hline $\begin{array}{l}\text { Diastolic Blood Pressure, } \\
\mathrm{mmHg}\end{array}$ & $80.1 \pm 3.2$ & $79.5 \pm 1.2$ & 0.591 \\
\hline $\mathrm{LDL}, \mathrm{mg} / \mathrm{dL}$ & $103 \pm 37.1$ & $102 \pm 36.4$ & 0.346 \\
\hline Triglycerides, mg/dL & $193.4 \pm 128$ & $191 \pm 128.4$ & 0.678 \\
\hline Hyperlipidemia, n (\%) & $4(8)$ & $4(8)$ & 1.000 \\
\hline LVEF, \% & $60.6 \pm 4.1$ & $59.4 \pm 4.6$ & 0.412 \\
\hline
\end{tabular}

BMI: Body-mass index; LDL: Low density lipoprotein; LVEF: Left ventricular ejection fraction.

When the values for $\mathrm{ICEB}$ and $\mathrm{ICEBc}$ between the two groups were compared (table 2), the patient group with T1DM tended to have higher iCEBc values compared to the healthy group ( $5.1 \pm 0.5$ vs $4.7 \pm 0.4, p<0.001)$. However, there was no statistically significant difference between the iCEB in the control and T1DM patient group ( $4.3 \pm 0.4$ vs $4.3 \pm 0.4, p=$ 0.402).

Table 2. Electrocardiographic evaluation of the participants

\begin{tabular}{lccc}
\hline & $\begin{array}{c}\text { T1DM group } \\
(\mathbf{n}=5 \mathbf{0})\end{array}$ & $\begin{array}{c}\text { Control group } \\
(\mathbf{n}=\mathbf{5 0})\end{array}$ & P value \\
\hline HR, beats/min & $83.1 \pm 9.8$ & $78.9 \pm 13.3$ & 0.019 \\
R-R, ms & $729.5 \pm 61.5$ & $769 \pm 108$ & 0.036 \\
PR, ms & $\begin{array}{c}147.7(132.3- \\
157.2)\end{array}$ & $\begin{array}{c}147.8(131.5- \\
149.4)\end{array}$ & 0.798 \\
QT, ms & $364.7 \pm 21.6$ & $368.2 \pm 23.8$ & 0.457 \\
QTc, ms & $425 \pm 20.4$ & $397.6 \pm 10.6$ & $<0.001$ \\
QRS duration, ms & $84.5 \pm 7.5$ & $86 \pm 6.4$ & 0.204 \\
Tp-Te, ms & $79.1 \pm 6.4$ & $73.2 \pm 5.3$ & 0.029 \\
iCEB & $4.3 \pm 0.4$ & $4.3 \pm 0.4$ & 0.402 \\
iCEBC & $5.1 \pm 0.5$ & $4.7 \pm 0.4$ & $<0.001$ \\
\hline
\end{tabular}

iCEB: index of Cardiac Electrophysiological Balance, HR: Heart Rate, iCEBC: index of Cardiac Electrophysiological Balance with Heart Rate Correction. 


\section{Discussion}

Considering the findings of the study, it was found that $\mathrm{iCEBC}$, resting heart rate and baseline QTc interval were higher in patients with T1DM than in healthy individuals. To our knowledge, this study is the first to provide evidence that T1DM is a significant change in ICEB and ICEBc in adults.

The patient group with DM is known to be at risk of ventricular arrhythmia and subsequent sudden cardiac death (12). The pathophysiological mechanisms of arrhythmias in diabetic patients have not been clearly revealed. Prolonged hyperglycemia has been blamed for the development and increase of fibrosis in myocardial tissue $(13,14)$. Whatever is the reason for myocardial fibrosis, it can cause damage to the myocardial conduction pathways and the formation of micro-reentry circuits. Ventricular arrhythmias such as ventricular fibrillation, ventricular tachycardia, or ventricular extrasystole can also be triggered by an impaired electrical axis of the heart and increased sympathetic activity (15).

Diabetic autonomic neuropathy involves many organs, including the cardiovascular system can affect. Cardiac autonomic neuropathy causes dysfunction by affecting the cardiac sympathetic and parasympathetic nervous system and may lead to sudden death. QT interval, which can be easily calculated from ECG, is an independent predictor of cardiovascular arrhythmia and subsequent sudden death in patients with type $2 \mathrm{DM}(16)$. However, as the QT interval is affected by heart rate, QTc is a better measure. QTc has been used to reflect cardiac autonomic neuropathy (17). Prolonged QTc duration brings with it the risk of increased ventricular arrhythmia (ventricular fibrillation/tachycardia, ventricular extrasystole, etc.) and sudden death, especially Torsades de Pointes (18). There are many studies on the presence and importance of prolonged QTc interval in DM $(19,20)$. In our study, in parallel with the studies in the literature, we found that the QTc interval was significantly prolonged in the group with DM.

$\mathrm{Tp}$-Te range is also another ventricular arrhythmia predictor indicating ventricular repolarization. It is another predictor of ventricular arrhythmia indicating ventricular repolarization. In our study, we found that Tp-Te was prolonged in the group with DM. It has been shown to be associated with ventricular arrhythmias and sudden death even when QTc is normal (21). In a study in the literature, $R-R$ range variations in patients with type $2 \mathrm{DM}$ have been evaluated and it has been related to cardiac neuropathy in these patients (22). Although a small significant difference was found in the R-R distance in our study, no significant difference was found in the PR distance.

Index of cardiac electrophysiological balance reflects the dynamic balance between depolarization (QRS duration) and repolarization (QT interval). Slight changes in iCEB can be harmless, whereas excessive changes (increase or decrease) can cause severe arrhythmias (23). iCEB appears to be a relatively new ECG parameter that does not require any invasive procedure, and there is evidence that it may be a useful ECG parameter in predicting TdP and non-TdP mediated ventricular arrhythmias (24). Increasing iCEB is associated with TdPs (23). In our study, although ICEB was similar between the T1DM and healthy groups, ICEBc was revealed to be significantly greater in T1DM groups. The iCEB was similar between the groups, and this increase in iCEBc is mainly due to the similar mean QRS durations of the groups and the increased QTc interval in the T1DM group. Our study is the first to report a significant increase in iCEBc in T1DM patients compared to healthy subjects.

According to our study findings, T1DM may pose an additional risk for ventricular arrhythmias.

\section{Limitations}

The relatively small number of patients is one of the main limitations of the study. Manual calculation of measurements may be a limitation, even if they are made with the help of a computer software program. Another limitation may be that evaluation is made only with surface ECG parameters and not with long-term ambulatory ECG monitoring methods. The fact that the study was retrospective and the patients did not have any clinical follow-up related to arrhythmia is a major limitation.

\section{Conclusions}

This study shows that these relatively new repolarization indices and potential electrocardiographic predictors of ventricular arrhythmias are significantly increased in T1DM. In conclusion, iCEBc increases significantly in patients with T1DM, compared with the healthy subjects.

Ethical Approval: Ethics approval was obtained from the ethics committee of Tokat Gaziosmanpasa University with date: 19.08.2020, number: 20-KAEK-123. The researchers state that they accept the ethical principles and conduct the research accordingly. This study was carried out in accordance with the Helsinki Declaration of 1975, which was updated in 2013.

\section{Author Contributions:}

\section{Concept: C.Z.Z.}

Literature Review: Ç.Z.

Design : S.E.Ö.

Data acquisition: Ç.Z.

Analysis and interpretation: C..Z.

Writing manuscript: S.E.Ö.

Critical revision of manuscript: S.E.Ö.

Conflict of Interest: The authors have no conflicts of interest to declare.

Financial Disclosure: We did not use any external funding source for our study.

\section{References}

1. Vasiliadis I, Kolovou G, Mavrogeni S, Nair DR, Mikhailidis DP. Sudden cardiac death and diabetes mellitus. J Diabetes Complications. 2014;28(4):573-9.

2. Kyrgios I, Rousso I, Varlamis G, Karavanaki K. Children and adolescents with type 1 diabetes mellitus have a sixfold 
greater risk for prolonged QTc interval. J Pediatr Endocrino Metab. 2014;27(3-4):237-43.

3. Panikkath R, Reinier K, Uy-Evanado A, Teodorescu C, Hattenhauer J, Mariani R, et al. Prolonged Tpeak-to-tend interval on the resting ECG is associated with increased risk of sudden cardiac death. Circ Arrhythm Electrophysiol 2011;4(4):441-7.

4. Akboga MK, Gulcihan Balci K, Yilmaz S, Aydin S, Yayla C, Ertem AG, ve ark. Tp-e interval and Tp-e/QTc ratio as novel surrogate markers for prediction of ventricular arrhythmic events in hypertrophic cardiomyopathy. Anatol J Cardiol 2017;18(1): 48-53.

5. Castro-Torres $Y$, Carmona-Puerta R, Katholi RE. Ventricular repolarization markers for predicting malignant arrhythmias in clinical practice. World J Clin Cases 2015;3 (8):70520.

6. Lu HR, Yan GX, Gallacher DJ. A new biomarker-index of cardiac electrophysiological balance (iCEB)-plays an important role in drug-induced cardiac arrhythmias: beyond QT-prolongation and Torsades de Pointes (TdPs). J Pharmacol ToxicolMethods 2013;68(2):250-9.

7. Robyns T, Lu HR, Gallacher DJ, Garweg C, Ector J, Willems R, et al. Evaluation of index of cardio-electrophysiological balance (iCEB) as a new biomarker for the identification of patients at increased arrhythmic risk. Ann Noninvasive Electrocardiol 2016; 21(3):294-304.

8. American Diabetes Association. Classification and Diagnosis of Diabetes: Standards of Medical Care in Diabetes -2018. Diabetes Care. 2018;41(1):13-27.

9. Lang RM, Bierig M, Devereux RB, Flachskampf FA, Foster $E$, Pellikka PA, et al. Chamber Quantification Writing Group; American Society of Echocardiography's Guidelines and Standards Committee; European Association of Echocardiography. Recommendations for chamber quantification: a report from the American Society of Echocardiography's Guidelines and Standards Committee and the Chamber Quantification Writing Group, developed in conjunction with the European Association of Echocardiography, a branch of the European Society of Cardiology. J Am Soc Echocardiogry 2005;18:1440-63

10. Usalp S, Kemal H, Akpınar O, Cerit L, Duygu H. Does protein adding to diet affect sportsmen's cardiovascular system? Cukurova Med J 2020;45(4):1428-35.

11. Bazett H. An analysis of the time relations of electrocardiograms. Heart 1920;7: 353-70.

12. Cox AJ, AzeemA, Yeboah J, Soliman EZ, Aggarwal SR, Bertoni $A G$, et al. Heart rate-corrected QT interval is an independent predictor of all-cause and cardiovascular mortality in individuals with type 2 diabetes: the Diabetes Heart Study. Diabetes Care. 2014;37(5):1454-61.

13. Mandala S, Di TC. ECG Parameters for malignant ventricular arrhythmias: a comprehensive review. J Med Biol Eng. 2017;37(4):441-53.

14. Kato $T$, Yamashita $T$, Sekiguchi $A$, Sagara K, Takamura M, Takata $S$, et al. What are arrhythmogenic substrates in diabetic rat atria? J Cardiovasc Electrophysiol. 2006;17(8):8904.

15. Piers SR, Everaerts K, Van der Geest RJ, Hazebroek MR, Siebelink HM, Pison LA, et al. Myocardial scar predicts monomorphic ventricular tachycardia but not polymorphic ventricular tachycardia or ventricular fibrillation in nonischemic dilated cardiomyopathy. Heart Rhythm.
2015;12(10):2106-14.

16. Cox A, Azeem A, Yeboah J, Soliman EZ, Aggarwal SR, Bertoni $A G$, et al. Heart rate-corrected qt interval is an independent predictor of all-cause and cardiovascular mortality in individuals with type 2 diabetes: the diabetes heart study. Diabetes Care. 2014;37(5):1454-61.

17. Uysal F, Ozboyaci E, Bostan O, Saglam H, Semizel E, Cil E. Evaluation of electrocardiographic parameters for early diagnosis of autonomic dysfunction in children and adolescents with type-1 diabetes mellitus. Pediatr Int 2014; 56: $675-80$

18. Youssef OI, Farid SM. QTc and QTd in children with Type 1 diabetes mellitus during diabetic ketoacidosis. ISRN Pediatr 2012; 2012: 619107.

19. Kittnar O. Electrocardiographic changes in diabetes mellitus. Physiol Res 2015; 64(5): 559-66.

20. Kuppermann N, Park J, Glatter K, Marcin JP, Glaser NS. Prolonged QT interval corrected for heart rate during diabetic ketoacidosis in children. Arch Pediatr Adolesc Med 2008;162(6): 544-9.

21. Panikkath R, Reinier K, Uy-Evanado A, Teodorescu C, Hattenhauer J, Mariani R, et al. Prolonged Tpeak-to-tend interval on the resting ECG is associated with increased risk of sudden cardiac death. Circ Arrhythm Electrophysiol. 2011;4(4):441-7.

22. Asakawa $H$, Onishi $M$, Hayashi I, Fukuda $A$, Tokunaga $K$. Comparison between coefficient of R-R interval variation and gastric emptying in type 2 diabetes mellitus patients. J Gastroenterol Hepatol. 2005;20(9):1358-64.

23. Lu HR, Yan GX, Gallacher DJ. A new biomarker--index of cardiac electrophysiological balance (iCEB)--plays an important role in drug-induced cardiac arrhythmias: beyond QT-prolongation and Torsades de Pointes (TdPs). J Pharmacol Toxicol Methods. 2013;68(2):250-259.

24. Robyns T, Lu HR, Gallacher DJ, Garweg C, Ector J, Willems R, et al. Evaluation of index of cardio-electrophysiological balance (iCEB) as a new biomarker for the identification of patients at increased arrhythmic risk. Ann Noninvasive Electrocardiol 2016; 21(3):294-304. 